\title{
FAKTOR-FAKTOR YANG BERPENGARUH TERHADAP LIKUIDITAS BANK SYARIAH ${ }^{1)}$
}

\author{
Muhammad Choirul Ichwan \\ Program Studi S1 Ekonomi Islam_fakultas EKonomi dan Bisnis-Universitas Airlangga \\ Email: choirulichwan24@gmail.com
}

Muhammad Nafik H.R

Departemen Ekonomi Syariah-Fakultas Ekonomi dan Bisnis-Universitas Airlangga

Email: muhammadnafik@yahoo.com

\begin{abstract}
:
This research aims to understand the influence of economic growth, rate of inflation, total funding, cost to income ratio, non performing financing, and financing to deposit ratio to liquidity of Islamic Bank. This Research uses a quantitative approach and a purposive sampling technique. The data used are collected through financial report of Islamic bank such as Muamalat Indonesia, BNI Syariah, BRI Syariah, Mandiri Syariah, and Mega Syariah period 2010-2014. Analysis of data is carried out by using the multiple linear regression analysis model. The result of this research is economic growth has significant to financing to deposit ratio.. This research suggests that to make the Bank not liquidity the Bank should increase the financing to deposit ratio.
\end{abstract}

Keywords: Influence, Financing To Deposit Ratio, Liquidity, Islamic Bank

\section{PENDAHULUAN}

Ekonomi Syariah merupakan ilmu pengetahuan sosial yang mempelajari masalah-masalah ekonomi rakyat yang diilhami oleh nilai - nilai Islam. Ekonomi Syariah berbeda dari kapitalisme, sosialisme, maupun negara kesejahteraan (welfare state).

Bank syariah merupakan lembaga keuangan yang menghimpun dan menyalurkan dana dari masyarakat kepada masyarakat. Bank Indonesia menyatakan bahwa bank syariah adalah bank yang menggunakan sistem dan operasi perbankan berdasarkan prinsip syariah Islam, yaitu mengikuti tata cara berusaha dan perjanjian berusaha yang dituntun oleh Al-quran dan Al-hadist, dan mengikuti tata cara berusaha dan perjanjian berusaha yang tidak dilarang oleh Al-quran dan Al-hadist. Bank sebagai penghimpun dana dari masyarakat agar 1) Jurnal ini merupakan bagian dari skripsi dari Muhammad Choirul Ichwan, NIM : 041114020 , yang diuji pada 12 Februari 2016 dapat memberikan keuntungan kepada bank baik pada bank syariah maupun konvensional. Dalam bank syariah keuntungan tersebut dapat diperoleh melalui sistem bagi hasil yang dapat diambil dari biaya-biaya operasional lainnya, sedangkan konvensional selisih antara pendapatan atas penanaman modal dan biaya-biaya pada periode tertentu.

QS. An-Nisa': 58

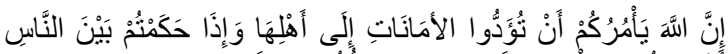

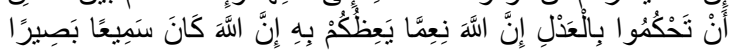

Innallāha yāmurukum an tūaddul amānāti-ilā ahlihā, waiza hakamtum bainān nāsi an tahkumū bil 'adl'i, innallāha ni-'immā ya'izukum bihi, innallākāna sami'am basirā.

Artinya: "Sesungguhnya Allah menyuruh kamu menyampaikan amanat kepada yang berhak menerimanya, dan (menyuruh kamu) apabila menetapkan 
hukum di antara manusia supaya kamu menetapkan dengan adil. Sesungguhnya Allah memberi pengajaran yang sebaikbaiknya kepadamu. Sesungguhnya Allah adalah Maha Mendengar lagi Maha Melihat."

Bank syariah memiliki kewajiban untuk melunasi atau disebut juga dengan likuiditas. Likuiditas merupakan salah satu faktor penentu sehatnya perbankan syariah dalam melunasi dana para deposannya yang ingin menarik kembali kredit yang diberikan dengan menggunakan rasio FDR (Financing to Deposit Ratio) (Muljono, 1996). Rasio tersebut berbanding terbalik dengan rasio profitabilitas karena rasio profitabilitas digunakan untuk mengukur efektivitas perusahaan untuk mendapatkan keuntungan, sehingga semakin tinggi rasio profitabilitas maka rasio likuiditas semakin kecil. Hal tersebut disebabkan karena dana yang diperlukan untuk membiayai kreditnya semakin kecil (Muljono, 1999). Namun semakin kecil rasio likuiditas akan berpengaruh pada naiknya tingkat profitabilitas. Berdasarkan data statistik perbankan OJK, per November 2013 rasio Financing To Deposit Ratio (FDR) bank umum syariah mencapai 121,46\%.

Tidak semua lembaga keuangan syariah dalam hal ini bank syariah dapat memenuhi kewajibannya untuk mencapai likuiditas. Pengelolaan likuiditas ini sangatlah berpengaruh pada perkembangan lembaga itu sendiri dan perekonomian negara secara luas, karena likuiditas sangat penting bagi keberlangsungan operasional bank. Pengelolaan dan manajemen likuiditas yang tidak baik akan menimbulkan permasalahan yang serius seperti krisis yang terjadi pada sektor keuangan di tahun 1997.

Bank yang berbasis syariah terhitung masih baru di Indonesia sehingga dalam pemenuhan kewajiban terutama kewajiban jangka pendek yakni likuiditas memiliki beberapa kendala salah satunya adalah kurangnya akses untuk memperoleh pendanaan jangka pendek. Penghimpunan Dana Pihak Ketiga (DPK) sangat penting bagi bank syariah karena hal tersebut berpengaruh dalam penghimpunan dana pihak ketiga yang nantinya dana tersebut dakan disalurkan kembali kepada masyarakat melalui pembiayaan. DPK dalam bentuk Giro Wadi'ah, Tabungan Mudharabah dan Deposito Mudharabah. Melalui hal tersebut peran penting likuiditas bank untuk mengukur keberhasilan bank sebagai perantara keuangan. Selain itu bank syariah memberikan pembiayaan yang disalurkan kepada masyarakat yang membutuhkan modal dan bank mendapatkan bagi hasil atas pembiayaan tersebut. Dalam proses penyaluran pembiayaan tersebut tidak terlepas dari risiko pembiayaan. Risiko pembiayaan tersebut dihitung menggunakan rasio NPF (Net Performing Financing). NPF merupakan rasio perbandingan antara total pembiayaan bermasalah dengan total pembiayaan 
yang diberikan kepada debitur. NPF dapat dijadikan indikator untuk melihat kelancaran pembiayaan sehingga mempengaruhi naik turunnya FDR. Selain itu faktor dari luar atau eksternal juga berpengaruh dalam mempengaruhi tingkat likuiditas bank syariah seperti tingkat inflasi. Inflasi merupakan peristiwa moneter yang menunjukkan kecenderungan akan naiknya harga barang-barang secara umum, yang berarti terjadinya penurunan nilai vang (Judisseno, 2005). Inflasi akan memberikan dampak terhadap perekonomian terutama perkonomian Indonesia, termasuk sector perbankan. Pengaruh inflasi terhadap sector perbankan dapat terjadi karena masyarakat cenderung mengurangi saving, dan akhirnya asset perbankan secara riil menurun. Hal tersebut akan berdampak pada kemampuan pihak perbankan dalam pernyaluran pembiayaan maupun kreditnya, sehingga kinerja fungsi intermediasi bank yang bersangkutan menurun.

Banyak bank yang harus bangkrut karena mengalami likuidasi. Menurut peraturan Lembaga Penjamin Simpanan Likuidasi nomor 1 tahun 2010 tentang likuidasi bank pada pasal 1 angka 12 menyebutkan likuidasi bank adalah salah suatu bentuk tindakan penyelesaian seluruh aset dan kewajiban bank sebagai akibat pencabutan izin usaha dan pembubaran badan hukum bank. Salah satu bank syariah yang mengalami likuidasi adalah PT. BPRS Babussalam. Menurut laporan yang ada Lembaga Penjamin Simpanan (LPS) menyebutkan likuidasi dari bank PT. BPRS Babussalam tidak ada kewajiban yang bisa dibayar dari hasil pencairan aset, bahkan untuk biaya likuidasi harus dipinjam dari Lembaga Penjamin Simpanan (LPS).

Tingkat NPF, BOPO, PYD, Inflasi, Pertumbuhan ekonomi dan FDR dapat dilihat pada gambar berikut:

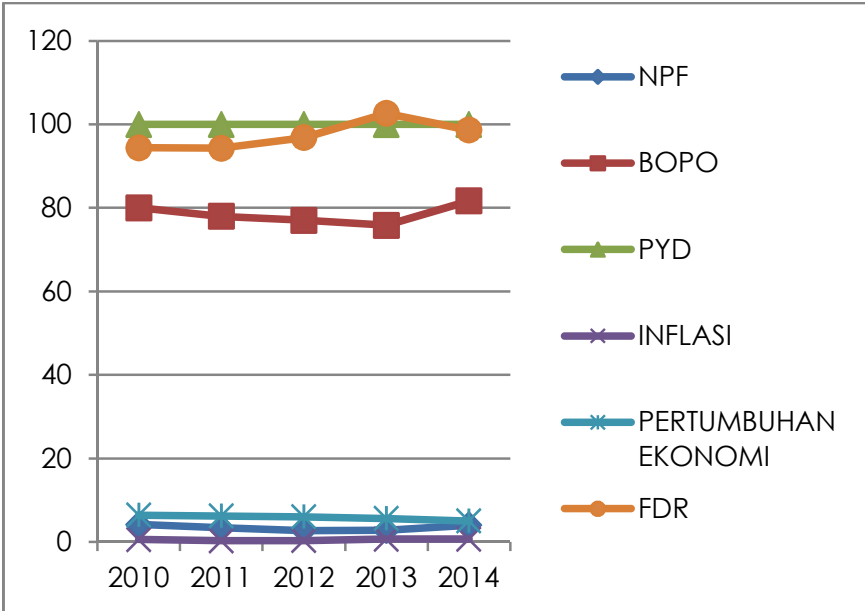

Sumber: Statistik Perbankan Syariah pada OJK tahun 2010-2014

\section{Gambar 1.1 Data SPS, PDB dan Inflasi Tahun 2010-2014}

Dari gambar 1.1 terlihat bahwa mengalami peningkatan secara bertahap dengan presentase terendah $94,285 \%$ dan tertinggi sebesar 102,63\%. Peningkatan FDR tersebut terjadi karena adanya kenaikan tingkat pembiayaan kepada nasabah yang diberikan. Tingkat NPF juga mengalami penurunan dan kenaikan yang fluktuatif. Dapat dilihat pada tahun 2012 memiliki rasio sebesar $2,72 \%$ dan 
Ichwan, et al/Jurnal Ekonomi Syariah Teori dan Terapan Vol. 3 No. 2 Februari 2016: 144-157; FAKTOR-FAKTOR YANG BERPENGARUH TERHADAP LIKUIDITAS BANK SYARIAH

mengalami peningkatan pada tahun 2014 sebesar 4,04\%, peningkatan tersebut terjadi karena pembiayaan bermasalah pada tahun itu mengalami kenaikan sehingga kinerja bank menurun dan dana yang disalurkan kurang optimal. Biaya Operasional terhadap Pendapatan Operasional juga mengalami penurunan secara bertahap terhitung dari awal tahun 2010 dan mengalami peningkatan kembali pada tahun 2014 sebesar 81,69\%. Penurunan tersebut sempat terjadi karena adanya penurunan tingkat pembiayaan yang dilakukan oleh masyarakat akibat kurangnya minat atas pengalokasian dana pada bank. Pertumbuhan ekonomi mengalami penurunan yang signifikan dari awal tahun 2010 hingga tahun 2014. Hal tersebut berbanding terbalik dengan FDR yang mengalami peningkatan dari tahun ke tahun meskipun sempat mengalami penurunan dengan selisih sebesar $3.49 \%$. Tingkat pembiayaan yang diberikan (PYD) mengalami kenaikan yang signifikan meskipun sempat mengalami penurunan sebesar $99,97 \%$ pada tahun 2011 tetapi hal tersebut mengalami peningkatan yang stabil hingga tahun 2014 sebesar 100\%.

Berdasarkan permasalahan yang telah dijabarkan, peneliti ingin melakukan analisis mengenai faktor-faktor yang berpengaruh terhadap likuiditas bank syariah. Faktor-faktor tersebut antara lain NPF, BOPO, PYD, Inflasi, Pertumbuhan ekonomi dan FDR
Penelitian ini dibuat untuk mengetahui faktor apa saja yang berpengaruh terhadap likuiditas bank syariah.

\section{LANDASAN TEORI}

Lembaga keuangan bank atau bank merupakan lembaga keuangan yang memberikan jasa keuangan yang paling lengkap, di samping menyalurkan dana atau memberi pinjaman (kredit) juga usaha menghimpun dana dari masyarakat luas dalam bentuk simpanan. Kemudian usaha bank dalam bentuk lainnya memberikan jasa yang mendukung dan memperlancar kegiatan memberikan pinjaman dengan kegiatan memberikan pinjaman dengan kegiatan menghimpun dana.

Pengertian Bank menurut UndangUndang Republik Indonesia No.7 tahun 1992 tentang perbankan, yang telah diubah dengan Undang-Undang No.10 tahun 1998 "Bank adalah badan usaha yang menghimpun dana dari masyarakat dalam bentuk simpanan dan menyalurkannya kepada masyarakat dalam bentuk kredit dan atau bentukbentuk lainnya dalam rangka meningkatkan taraf hidup rakyat banyak.". Seperti yang ada dalam QS. AlBaqarah : 282.

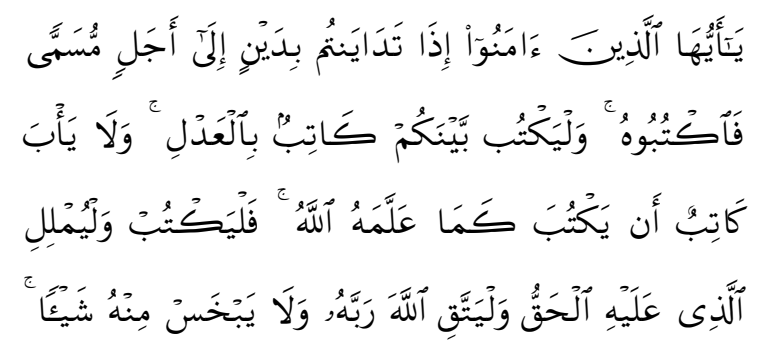




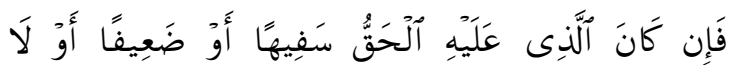

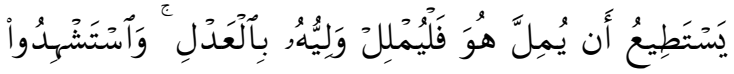

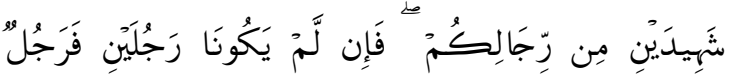

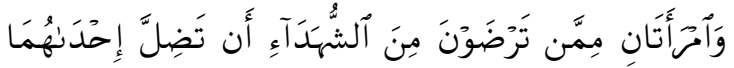

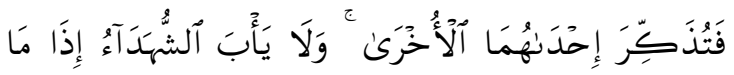

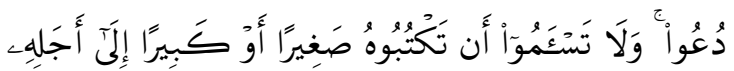

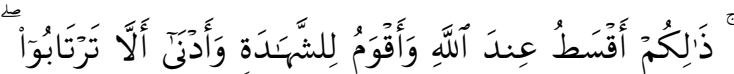

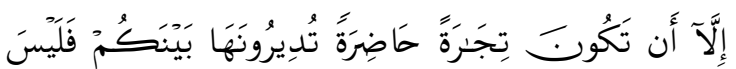

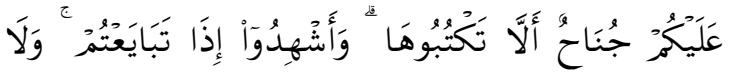

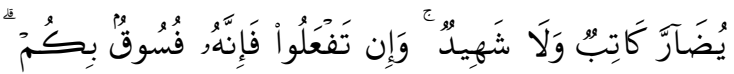

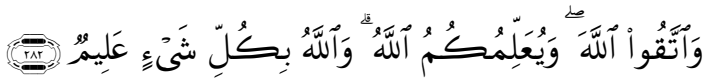

yā ayyuhā alladziina āmanū

idzā tadāyantum bidaynin ilā ajalin musamman fauktubūhu walyaktub baynakum kātibun bial'adli walā ya'ba kātibun an yaktuba kamā 'allamahu allāhu falyaktub walyumlili alladzii 'alayhi alhaqqu walyattaqi allāha rabbahu walā yabkhas minhu syay-an fa-in kāna alladzii 'alayhi alhaqqu safiihan aw dha'iifan aw lā yastathii'u an yumilla huwa falyumlil waliyyuhu bial'adli waistasyhiduu syahiidayni min rijālikum fa-in lam yakuunā rajulayni farajulun waimra-atāni mimman tardhawna mina alsysyuhadā-i an tadhilla indāhumā fatudzakkira ihdāhumā al

ukhrā walā ya'ba alsysyuhadāu

idzā mādu'ū walā tas-amū an taktubūhu shaghiiran aw kabiiran ilā ajalihi dzālikum aqsathu 'inda allāhi waaqwamu lilsysyahādati waadnā allā tartābū illā-an takūna tijā ratan hadiratan tudirūnahā baynakum falaysa 'alaykum junāhun allā taktubuuhāwa-asyhidū idzā tabāya'tum walā yudārra kātibun walaa syahiidun wa-in taf'aluu fa-innahu fusūqun bikum waittaqū allāha wayu'allimukumu allāhu waallāhu bikulli syay-in 'aliimun
Artinya:

"Hai orang-orang yang beriman, apabila kamu bermualah tidak secara tunai untuk waktu yang ditentukan, hendaklah kamu menuliskannya. Dan hendaklah seorang penulis diantara kamu menuliskannya dengan benar. Dan janganlah penulis enggan menuliskannya sebagaimana Allah telah mengajarkannya, maka hendaklah ia menulis, dan hendaklah orang yang berhutang itu mengimlakkan (apa yang akan ditulis itu), dan hendaklah ia bertakwa kepada Allah Tuhannya, dan janganlah ia mengurangi sedikitpun daripada hutangnya".

Sebagai salah satu lembaga kevangan bank adalah bank syariah yang menerapkan prinsip syariah pada setiap instrumen dalam kebijakan moneter yang ditetapkan oleh pemerintah. Selain itu bank juga harus dapat menjaga likuiditasnya agar tidak mengalami pailit. Menurut Sutrisno (2009:215), "Likuiditas adalah kemampuan perusahaan untuk membayar kewajiban-kewajibannya yang segera dipenuhi."

Landasan hukum bank syariah di Indonesia diatur dalam Undang-undang nomor 21 tahun 2008 tentang Perbankan Syariah. Dalam aturan Undang-undang Perbankan syariah pasal 1 pengertian bank syariah, bank umum syariah, bank pembiayaan rakyat syariah, dan unit usaha syariah adalah sebagai berikut:

a. Bank Syariah adalah Bank yang menjalankan kegiatan usahanya Berdasarkan Prinsip Syariah dan menurut jenisnya terdiri atas Bank Umum Syariah dan Bank Pembiayaan Rakyat Syariah.

b. Bank Umum Syariah adalah Bank Syariah yang dalam kegiatannya 
memberikan jasa dalam lalu lintas pembayaran.

c. Bank Pembiayaan Rakyat Syariah adalah Bank Syariah yang dalam kegiatannya tidak memberikan jasa dalam lalu lintas pembayaran.

d. Unit Usaha Syariah, yang selanjutnya disebut UUS, adalah unit kerja dari kantor pusat Bank Umum Konvensional yang berfungsi sebagai kantor induk dari kantor atau unit yang melaksanakan kegiatan usaha berdasarkan Prinsip Syariah, atau unit kerja di kantor cabang dari suatu Bank yang berkedudukan di luar negeri yang melaksanakan kegiatan usaha secara konvensional yang berfungsi sebagai kantor induk dari kantor cabang pembantu syariah dan atau unit syariah. Selain itu bank syariah memiliki tujuan dengan menjalankan prinsipnya, menjauhkan riba dalam semua jenis transaksinya. Selain itu prinsip perbankan syariah lebih mengedepankan dasar kesetaraan (equality), keadilan (fairness) dan keterbukaan (transparency) dalam setiap transaksinya untuk mendapatkan keuntungan yang halal. Jika tidak, tentu bank syariah disebut tidak amanah dalam mengelola dana-dana yang diinvestasikan masyarakat. Maka bank syariah harus menyelaraskan antara tujuan profit dengan aspek moralitas Islam yang melandasi semua operasionalnya (Harahap, 2005).
Secara umum laporan keuangan bank syariah dapat dijelaskan melalui hal berikut:

1. Laporan keuangan yang menggambarkan fungsi bank Islam sebagai investor, hak dan kewajibannya, dengan tidak memandang tujuan bank Islam itu dari masalah investasinya apakah ekonomi atau sosial. Mekanisme investasi yang digunakan terbatas hanya kepada beberapa cara yang diperbolehkan syariah. Karenanya laporan keuangan meliputi:

a) Laporan posisi keuangan.

b) Laporan laba rugi.

c) Laporan arus kas.

d) Laporan laba ditahan atau laporan perubahan pada saham pemilik.

2. Sebuah laporan keuangan yang menggambarkan perubahan dalam investasi terbatas, yang dikelola oleh bank syariah untuk kepentingan masyarakat, baik berdasarkan kontrak mudharabah atau kontrak perwakilan. Laporan semacam ini akan dirujuk sebagai "Laporan Perubahan dalam Investasi Terbatas."

3. Laporan keuangan yang menggambarkan peran bank syariah sebagai fiduciary dari dana yang tersedia untuk jasa sosial ketika jasa semacam itu diberikan melalui dana terpisah.

a) Laporan sumber dan penggunaan dana zakat dan dana sosial. 
b) Laporan sumber dan penggunaan dana qardh.

Analisis rasio adalah suatu periode analisa untuk mengetahui hubungan dari pos-pos tertentu dalam neraca atau laporan laba-rugi individual atau kombinasi kedua laporan tersebut (Munawir, 2002). Pada umumnya rasiorasio yang digunakan dalam bank syariah tidak berbeda jauh dengan rasio yang ada pada bank konvensional, seperti berikut:

a. Rasio likuiditas merupakan salah satu ukuran bagi bank untuk memenuhi kewajiban jangka pendek seperti hutang-hutang jangka pendek.

b. Rasio profitabilitas merupakan rasio menunjukkan tingkat efektivitas yang dicapai melalui usaha operasional bank yang digunakan untuk mengukur kemampuan dalam memperoleh laba atau keuntungan.

c. Rasio solvabilitas merupakan rasio yang mengukur perbandingan dana yang disediakan oleh pemilik dana yang dipinjam oleh kreditur dari perusahaan tersebut.

Likuiditas merupakan salah satu faktor penentu sehatnya perbankan syariah dalam melunasi dana para deposannya yang ingin menarik kembali kredit yang diberikan dengan menggunakan rasio FDR (Financing to Deposit Ratio) (Muljono, 1996).

Faktor berpengaruh terhadap likuiditas bank syariah a. Financing to Deposit Ratio (FDR) adalah rasio yang digunakan untuk mengukur likuiditas sebuah bank dalam memenuhi kembali penarikan dana yang dilakukan nasabah dengan mengandalkan pembiayaan yang diberikan sebagai sumber likuiditasnya, dengan cara membagi jumlah pembiayaan yang diberikan oleh bank terhadap Dana Pihak Ketiga (DPK).

b. Pertumbuhan ekonomi yang didefinisikan sebagai peningkatan dalam kemampuan dari suatu perekonomian dalam memproduksi barang-barang dan jasa-jasa. Dengan kata lain, pertumbuhan ekonomi lebih merujuk pada perubahan yang bersifat kuantitatif dan biasanya diukur dengan menggunakan data Product Domestic Bruto (PDB).

C. Inflasi merupakan peristiwa moneter yang menunjukkan kecenderungan akan naiknya harga barang-barang secara umum, yang berarti terjadinya penurunan nilai uang (Judisseno, 2005). Inflasi akan memberikan dampak terhadap perekonomian terutama perkonomian Indonesia, termasuk sektor perbankan. Pengaruh inflasi terhadap sektor perbankan dapat terjadi karena masyarakat cenderung mengurangi saving, dan akhirnya aset perbankan secara riil menurun.

d. Non Performing Financing adalah pembiayaan yang tidak menepati jadwal angsuran sehingga terjadi 
tunggakan. NPF merupakan risiko dari adanya pembiayaan yang disalurkan oleh bank kepada nasabah. Besar kecilnya NPF akan berpengaruh pada profitabilitas, karena hal tersebut mungkin dapat menurunkan tingkat profitabilitas pada tahun berjalan (Kharisma, 2012:2).

e. Pembiayaan yang diberikan, Mulyono (2004:4) menjelaskan bahwa pembiayaan adalah kemampuan untuk melaksanakan suatu pembelian atau dengan mengadakan suatu pinjaman dengan suatu janji pembayarannya dilakukan atau ditangguhkan pada suatu jangka waktu yang disepakati. Pembiayaan merupakan aktivitas bank syariah dalam menyalurkan dana kepada pihak lain selain bank berdasarkan prinsip syariah. Penerima pembiayaan mendapat kepercayaan dari pemberi pembiayaan, sehingga penerima pembiayaan berkewajiban untuk mengembalikan pembiayaan yang telah diterimanya sesuai dengan jangka waktu yang telah diperjanjikan dalam akad pembiayaan.

f. Biaya Operasional terhadap Pendapatan Operasional juga berpengaruh terhadap kemampuan bank dalam memenuhi kegiatan operasionalnya terhadap pendapatan operasionalnya (Dendawijaya, 2005). Semakin kecil rasio BOPO maka semakin efisien biaya operasional yang dikeluarkan bank bersangkutan (Almilia dan Herdiningtyas, 2005).

\section{METODE PENELITIAN}

\section{Pendekatan Penelitian}

Penelitian ini mengarah pada hasil yang akurat serta dapat memberikan gambaran umum (generalisasi) atas fenomena yang diteliti, sehingga pendekatan yang digunakan dalam penelitian ini adalah pendekatan kuantitatif.

\section{Jenis dan Sumber Data}

Menurut Sugiyono (2009:60) "variable penelitian pada dasarnya adalah segala sesuatu yang berbentuk apa saja yang ditetapkan oleh peneliti untuk dipelajari sehingga diperoleh informasi tentang hal tersebut, kemudian ditarik kesimpulannya". Sesuai dengan rumusan masalah dan model analisis yang telah dijelaskan sebelumnya, variabel yang akan digunakan dalam penelitian ini terdiri dari dua variable independen dan satu variable dependen. Variabel-variabel tersebut antara lain adalah:

a. Variabel independen adalah PYD, BOPO, NPF, Inflasi dan Pertumbuhan Ekonomi.

b. Variabel dependen adalah Financing to Deposit Ratio

Jenis data yang digunakan dalam penelitian ini adalah data sekunder. "Data sekunder adalah data yang diperoleh oleh suatu organisasi atau perusahaan dalam bentuk yang sudah jadi berupa publikasi" (Suprapto 2000:8 
Ichwan, et al/Jurnal Ekonomi Syariah Teori dan Terapan Vol. 3 No. 2 Februari 2016: 144-157; FAKTOR-FAKTOR YANG BERPENGARUH TERHADAP LIKUIDITAS BANK SYARIAH

dalam Nia, 2011). Data sekunder yang digunakan dalam penelitian ini adalah data Statistik Perbankan Syariah pada OJK dan laju pertumbuhan ekonomi dan inflasi pada Badan Pusat Statistik.

Sumber Data yang digunakan dalam penelitian ini bersumber dari laporan Statistik Perbankan Syariah pada OJK dan laju pertumbuhan ekonomi dan inflasi pada BPS serta sumber-sumber lain yang relevan berupa literatur penelitian terdahulu, makalah seminar, dan artikel dari internet.

\section{Prosedur Pengumpulan Data}

a. Populasi

Pengertian dari populasi menurut Anshori dan Iswati (2009:92) adalah "wilayah generalisasi yang terdiri atas obyek atau subyek yang mempengaruhi kuantitas dan karakteristik tertentu yang diterapkan peneliti untuk dipelajari dan ditarik kesimpulannya". Populasi yang digunakan dalam penelitian ini adalah perbankan syariah yang memiliki laporan kevangan likuiditas yang diserahkan kepada OJK secara periode semester 16 bulan).

b. Sampel

Di dalam penentuan atau
pemilihan sampel, metode yang
digunakan dalam pemilihan sampel
adalah purposive sampling. Menurut
Anshori dan Iswati (2009:105) "purposive sampling merupakan gambaran teknik penentuan sampel dengan pertimbangan tertentu". Kriteria sampel yang digunakan dalam penelitian ini adalah bank umum syariah yang telah berdiri lebih dari lima tahun. Sampel yang digunakan adalah Bank Muamalat Indonesia, Bank BNI Syariah, Bank BRI Syariah, Bank Mandiri Syariah dan Bank Mega Syariah yang memiliki laporan keuangan dengan kurun waktu 2010-2014.

Prosedur pengumpulan data dilakukan melalui tahap-tahap sebagai berikut:

1. Laporan keuangan Bank Umum Syariah selama lima tahun (2010-2014) secara lengkap.

2. Laporan Pertumbuhan Ekonomi (Produk Domestik Bruto) triwulanan atas lapangan usaha terhadap harga konstan tahun 2000 pada data Badan Pusat Statistik (BPS).

\section{Teknik Analisis Data}

Penelitian ini menggunakan teknik analisis regresi linier berganda. Analisis regresi linear berganda adalah analisis terhadap model regresi yang memiliki lebih dari dua variable independen. Teknik analisis ini digunakan untuk pengaruh variabel makro dan variabel mikro terhadap likuiditas bank syariah periode 2010-2014.

\section{HASIL DAN PEMBAHASAN}

Menurut uji asumsi klasik yang dilakukan pada variabel-variabel penelitian ini, tidak ditemukan data yang bias. Pada uji heteroskedastisitas, tidak terdapat hubungan antara variabel dependen dengan variabel independen 
sehingga bebas dari heteroskedastisitas. Uji multikolinearitas yang dilakukan tidak ada hubungan antar variabel masingmasing, hal ini membuktikan bahwa bebas dari multikolinearitas. Pada uji autokorelasi, nilai durbin watson berada di atas -2 dan lebih kecil dari pada 2 sehingga menunjukkan tidak ada korelasi antar variabel. Uji normalitas menunjukkan bahwa variabel-variabel dalam penelitian mempunyai distribusi yang normal.

a. Pengaruh Pembiaaan Yang Diberikan Terhadap Financing to Deposit Ratio

Dalam penelitian ini variabel pembiayaan yang diberikan memiliki tingkat $\dagger$ hitung sebesar 1,420 dengan signifikansi 0,163, maka hasil dari tersebut dapat disimpulkan bahwa nilai signifikan lebih besar dari tingkat signifikan yang telah ditentukan yaitu 0,05 . Hasil tersebut dapat disimpulkan bahwa PYD berpengaruh tidak signifikan terhadap FDR. Hasil penelitian ini yang menggunakan spss menunjukkan bahwa semakin besar tingkat pembiayaan yang diberikan maka rasio FDR akan menurun, hal tersebut disebabkan karena apabila pembiayaan yang diberikan kepada masyarakat disalurkan dengan tidak efektif maka akan berpengaruh pada keuntungan yang diperoleh bank juga akan menurun. Hal tersebut didukung oleh penelitian yang dilakukan oleh Purbaningsih (2010) yang menyatakan bahwa PYD berpengaruh tidak signifikan terhadap Financing to Deposit Ratio. b. Pengaruh Biaya Operasional terhadap Pendapatan Operasional terhadap Financing to Deposit Ratio.

Dalam penelitian ini variabel BOPO memiliki tingkat $t$ hitung sebesar $-1,680$ dengan signifikansi 0,100 , maka hasil dari tersebut dapat disimpulkan bahwa nilai signifikan lebih besar dari tingkat signifikan yang telah ditentukan yaitu 0,05 . Hasil tersebut dapat disimpulkan bahwa BOPO tidak berpengaruh signifikan terhadap FDR. Karena menurut penelitian sebelumnya, Dendawijaya (2005) rasio Biaya Operasional terhadap Pendapatan Operasional digunakan untuk mengukur tingkat efisiensi bank dalam menjalankan kegiatan operasionalnya, apabila semakin tinggi rasio BOPO makan rasio FDR akan menurun karena hal tersebut mengurangi pembiayaan yang disalurkan karena efisiensi biaya operasional juga tinggi.

c. Pengaruh Net Performing Financing terhadap Financing to Deposit Ratio.

Dalam penelitian ini variabel NPF memiliki tingkat $t$ hitung sebesar -1,291 dengan signifikansi 0,204, maka hasil dari tersebut dapat disimpulkan bahwa nilai signifikan lebih besar dari tingkat signifikan yang telah ditentukan yaitu 0,05. Hasil tersebut dapat disimpulkan bahwa NPF tidak berpengaruh signifikan tehadap FDR, dimana setiap kenaikan NPF akan menurunkan FDR. Rasio NPF yang tinggi akan berpengaruh terhadap kinerja intermediasi bank yang kurang optimal karena mengurangi perputaran bank 
Ichwan, et al/Jurnal Ekonomi Syariah Teori dan Terapan Vol. 3 No. 2 Februari 2016: 144-157; FAKTOR-FAKTOR YANG BERPENGARUH TERHADAP LIKUIDITAS BANK SYARIAH

atau menurunkan kesempatan bank untuk mendapatkan pendapatan. Apabila dana yang ada pada bank kurang maka pembiayaan yang diberikan kepada masyarakat juga akan menurun. Berdasarkan penelitian sebelumnya yang dilakukan oleh penelitian Firaldi (2013) dan Mulki (2011), menunjukkan bahwa NPF berpengaruh signifikan terhadap pembiayaan yang diberikan sehingga hal tersebut berpengaruh pada kemampuan bank dalam memenuhi kewajiban jangka pendek yang dihitung dengan rasio FDR.

d. Pengaruh Inflasi terhadap Financing to Deposit Ratio.

Dalam penelitian ini variabel Inflasi memiliki tingkat $\dagger$ hitung sebesar -2,206 dengan signifikansi 0,033 , maka hasil dari tersebut dapat disimpulkan bahwa nilai signifikan lebih kecil dari tingkat signifikan yang telah ditentukan yaitu 0,05. Hasil tersebut dapat disimpulkan bahwa Inflasi berpengaruh signifikan terhadap FDR, karena menurut hasil penelitian Supriyatna (2010) dan Nandadipa (2010) bahwa inflasi berpengaruh negatif terhadap rasio pembiayaan dikarenakan tabungan masyarakat (DPK) mengalami penurunan.

e. Pengaruh Pertumbuhan Ekonomi terhadap Financing to Deposit Ratio.

Pertumbuhan ekonomi dalam penelitian ini memiliki tingkat $\dagger$ hitung sebesar -3,933 dengan signifikansi 0,000, maka hasil dari tersebut dapat disimpulkan bahwa nilai signifikan lebih kecil dari tingkat signifikan yang telah ditentukan yaitu 0,05. Menurut hasil dalam penelitian ini pertumbuhan ekonomi berpengaruh signifikan terhadap FDR. Hasil ini serupa dengan penelitian yang dilakukan oleh Rahmawati (2005) yang hipotesis awalnya adalah pertumbuhan ekonomi berpengaruh positif terhadap Loan to Deposit Ratio (LDR) yaitu rasio yang sama dengan FDR pada bank syariah, namun hasil yang didapat adalah pertumbuhan ekonomi berpengaruh negatif terhadap LDR pada jangka pendek dan berpengaruh positif tetapi tidak signifikan terhadap LDR.

Pengaruh PYD, BOPO, NPF, Inflasi dan Pertumbuhan Ekonomi terhadap Financing to Deposit Ratio secara simultan

Uji F digunakan untuk menunjukkan apakah semua variabel independen yang ada dalam penelitian mempunyai pengaruh secara bersama-sama terhadap variabel dependen. Dasar pengambilan keputusannya adalah dengan membandingkan nilai F-hitung dengan F-tabel dan nilai probabilitas (sig.). apabila nilai F-hitung lebih besar dari nilai F-tabel (F-hitung > F-tabel), dan nilai probabilitas lebih kecil dari nilai $a=0,05$ (Sig < 0,05), maka dapat disimpulkan bahwa terdapat pengaruh yang signifikan secara simultan antara variabel independen dan dependen.

Hal tersebut didukung oleh penelitian yang dilakukan oleh Novitasari (2011) dengan judul Analisis faktor-faktor yang mempengaruhi Finance to Seposit Ratio (FDR) sebagai indikator Likuiditas pada perbankan syariah di Indonesia 
Ichwan, et al/Jurnal Ekonomi Syariah Teori dan Terapan Vol. 3 No. 2 Februari 2016: 144-157; FAKTOR-FAKTOR YANG BERPENGARUH TERHADAP LIKUIDITAS BANK SYARIAH

menjelaskan bahwa Faktor - faktor internal bank syariah (DPK, PYD, ROA, dan Penempatan pada Bl dan bank lain) yang menjadi variabel bebas penelitian ini berpengaruh dan siginifikan secara simultan terhadap FDR dan likuiditas. Dan labal Supriyatna (2010) yang berjudul Analisis pengaruh modal, Non Performing Financing (NPF) dan inflasi terhadap pembiayaan yang disalurkan, dan implikasinya terhadap Return On Assets (ROA) pada perbankan syariah di Indonesia. Menurut penelitian tersebut terbukti bahwa variabel PYD, BOPO, NPF, Inflasi dan Pertumbuhan Ekonomi berpengaruh secara simultan terhadap Financing to Deposit Ratio.

\section{SIMPULAN}

Berdasarkan hasil analisis dan pembahasan pada bab sebelumnya, maka dapat disimpulkan sebagai berikut :

1. Pembiayaan yang diberikan memiliki pengaruh yang tidak signifikan terhadap likuiditas bank syariah di Indonesia.

2. Biaya Operasional terhadap Pendapatan Operasional memiliki pengaruh yang tidak signifikan terhadap likuiditas bank syariah di Indonesia.

3. Net Performing Financing (NPF) memiliki pengaruh yang tidak signifikan terhadap likuiditas bank syariah di Indonesia.

4. Inflasi memiliki pengaruh yang tidak signifikan terhadap likuiditas bank syariah di Indonesia.
5. Pertumbuhan Ekonomi memiliki pengaruh yang signifikan terhadap likuiditas bank syariah di Indonesia dengan $t$ hitung $-3,650$ dengan signifikan 0,001 .

6. Variabel-variabel independen dalam penelitian ini seperti PYD, BOPO, NPF, Inflasi dan Pertumbuhan Ekonomi berpengaruh secara simultan terhadap Likuiditas bank syariah di Indonesia.

\subsection{Saran}

Berdasarkan simpulan tersebut, saran yang disampaikan dalam penelitian ini adalah :

1. Untuk Bank Syariah

Pertumbuhan Ekonomi sangat berpengaruh signifikan terhadap likuiditas bank syariah oleh karena itu perbankan syariah harus lebih peka terhadap perkembangan ekonomi yang terjadi di Indonesia terkait dengan banyaknya dana yang akan dihimpun dan yang akan disalurkan kepada masyarakat sehingga resiko ketika terjadinya pertumbuhan ekonomi yang tidak stabil bank akan dapat mengatasi permasalahan tersebut.

2. Untuk Otoritas Jasa Keuangan

Sebagai pengawas dan pengatur regulasi untuk perbankan syariah, disarankan pada OJK untuk mengawasi dan memberikan kebijakan yang disesuaikan dengan faktor eksternal perbankan syariah. Karena hal tersebut cukup berpengaruh terhadap likuiditas bank syariah.

3. Untuk penelitian selanjutnya 
Ichwan, et al/Jurnal Ekonomi Syariah Teori dan Terapan Vol. 3 No. 2 Februari 2016: 144-157; FAKTOR-FAKTOR YANG BERPENGARUH TERHADAP LIKUIDITAS BANK SYARIAH

$\begin{array}{rll}\text { Peneliti selanjutnya dapat } & \text { Finance terhadap Profitabilitas } \\ \text { melanjutkan penelitian ini dengan } & \text { Perbankan Syariah, skripsi Institut } \\ \text { variabel makro dan variabel mikro yang } & \text { Manajemen Telkom Bandung. }\end{array}$
kemungkinan berpengaruh terhadap FDR serta memperluas sampel penelitian bank syariah.

\section{DAFTAR PUSTAKA}

Al-Qur'an dan Terjemahannya. 1989.Mushaf Al-Qur'an Terjemahan. Departemen Agama. Jakarta: Mahkota Surabaya.

Almilia \& Herdiningtyas. 2005. Analisis Rasio

CAMEL terhadap Prediksi Kondisi

Bermasalah pada Lembaga

Perbankan Periode 2000-2002.

JurnalAkuntansidanKeuangan, Vol.7,

No.2, November.

Anshori, Muchlis dan Sri Iswati. 2009.

Metodologi Penelitian Kuantitatif.

Surabaya: Airlangga University Press

Daftar Statistik Perbankan Syariah. 2015.

Perkembangan Daftar Statistik

Perbankan Syariah pada Tahun 2010-

2014 (online) www.ojk.go.id diakses tanggal 24 Juli 2015

Daftar Pendapatan Domestik Bruto dan Inflasi. 2015.Perkembangan Laju Pertumbuhan Ekonomi dan Inflasi pada Tahun 2010-2014 (online) www.bps.go.id diakses tanggal 24 Juli 2015

Dendawijaya, Lukman. 2005. Manajemen Perbankan. Edisikedua, Cetakan Kedua. Bogor : Ghalia Indonesia.

Dea Naufal Kharisma. 2012.Pengaruh Dana Pihak Ketiga dan Non Performing Firaldi, Mufqi. 2013. Analisis Pengaruh Jumlah Dana Pihak Ketiga (DPK), Non Performing Financing (NPF) dan Tingkat Inflasi Terhadap Total Pembiayaan yang Diberikan Oleh Bank Pembiayaan Rakyat Syariah (BPRS) Di Indonesia. Skripsi. UIN Jakarta.

Harahap, Sofyan S, Wirosodan Muhammad Yusuf. 2005. AkuntansiPerbankanSyariah. Jakarta : LPFE Usakti.

Judisseno, Rimsky K. 2005. Sistem Moneter dan Perbankan Indonesia. Cetakan Kedua. Jakarta: Gramedia Pustaka Utama.

Muljono. 1999. Analisa Laporan Keuangan Untuk Perbankan. Edisi Revisi 1999, Cetakan 6, Jakarta : Djambatan.

Muljono. 1996. Bank Budgeting Profit Planning \& Control. Yogyakarta: BPFEYOGYAKARTA.

Mulki, Khaikal. 2011 . Analisis Pengaruh Moral Hazard terhadap Pembiayaan

Bank Syariah di Indonesia. Skripsi. Jakarta: UIN Syarif Hidayatullah.

Mulyono, S. 2004. Riset Operasi. Jakarta: Lembaga Penerbit Fakultas Ekonomi UI. Munawir, S. 2002. Analisis Laporan Keuangan. EdisiKedua. Yogyakarta : YPKN.

Nandadipa. 2010.Analisis Pengaruh CAR, NPL, Inflasi, Pertumbuhan DPK dan Exchange Rate terhadap LDR. Skripsi. 
Ichwan, et al/Jurnal Ekonomi Syariah Teori dan Terapan Vol. 3 No. 2 Februari 2016: 144-157; FAKTOR-FAKTOR YANG BERPENGARUH TERHADAP LIKUIDITAS BANK SYARIAH

Fakultas Ekonomi Universitas

Diponegoro Semarang.

Novitasari. 2011. Analisis Faktor-Faktor yang Mempengaruhi Finance to Deposit Ratio (FDR) sebagai Indikator Likuiditas Pada Perbankan Syariah di Indonesia. Jurnal Ekonomi, 2011 jimfeb.ub.ac.id

Rahmawati. 2005. Relevansi Kandungan Informasi Komponen Arus Kas dan Laba dalam Memprediksi Arus Kas Masa Depan. Jurnal Akuntansi dan Bisnis, vol. $5, \mathrm{n} 0.1$

Sugiyono. (2009). Metode Penelitian Bisnis (Pendekatan Kuantitatif, Kualitatif, dan R\&D). Bandung: Alfabeta.

Undang-Undang Republik Indonesia No.7 Tahun 1992 Tentang Perubahan atas Undang-Undang No.7 tahun 1992 Tentang Perbankan.

Sutrisno. 2009. Manajemen Keuangan Teori, Konsep dan Aplikasi. Yogyakarta: Ekonisia.

Wirawatipertiwi, Nia. 2011.Pengaruh Kinerja Kevangan Terhadap Pendapatan Saham Sebelum Dan Selama Saham Terdaftar Di Jakarta Islamic Index.Surabaya. Skripsi Universitas Airlangga. 